Meta

Journal des traducteurs

Translators' Journal

\title{
Communicative Rituals and Audiovisual Translation - Representation of Otherness in Film Subtitles
}

\section{Marie-Noëlle Guillot}

Volume 61, numéro 3, décembre 2016

URI : https://id.erudit.org/iderudit/1039221ar

DOI : https://doi.org/10.7202/1039221ar

Aller au sommaire du numéro

Éditeur(s)

Les Presses de l’Université de Montréal

ISSN

0026-0452 (imprimé)

1492-1421 (numérique)

Découvrir la revue

Citer cet article

Guillot, M.-N. (2016). Communicative Rituals and Audiovisual Translation Representation of Otherness in Film Subtitles. Meta, 61(3), 606-628. https://doi.org/10.7202/1039221ar
Résumé de l'article

Dans une étude comparative de salutations dans les échanges entre amis en Australie et en France (Béal et Traverso 2010), les pratiques interactionnelles observées dans le corpus rassemblé présentent certes des points communs, mais aussi des spécificités verbales et non verbales dont la récurrence est interprétée comme révélant un lien entre styles conversationnels et valeurs culturelles sous-jacentes.

Comme le fait également la pragmatique comparée en général, cette conclusion soulève des questions de représentation pour l'audiovisuel et la traduction audiovisuelle : comment les routines conversationnelles sont-elles projetées dans les dialogues de film et dans leurs traductions par le biais du sous-titrage ou du doublage ? Quel est l'impact de ces représentations sur les spectateurs? Ces questions servent de base à une étude de cas qui s'attache dans cet article aux salutations et autres routines conversationnelles dans les sous-titres en anglais de trois films contemporains, deux en français, un en espagnol. Elles sont abordées dans une perspective de pragmatique comparée et avec pour toile de fond la théorie du mode de Fowler $(1991,2000)$, aux fins d'évaluer le potentiel textuel des sous-titres de film à signifier dans une perspective interculturelle. 


\title{
Communicative Rituals and Audiovisual Translation - Representation of Otherness in Film Subtitles
}

\author{
MARIE-NÖ̈LLE GUILLOT \\ University of East Anglia, Norwich, UK \\ m.guillot@uea.ac.uk
}

\section{RÉSUMÉ}

Dans une étude comparative de salutations dans les échanges entre amis en Australie et en France (Béal et Traverso 2010), les pratiques interactionnelles observées dans le corpus rassemblé présentent certes des points communs, mais aussi des spécificités verbales et non verbales dont la récurrence est interprétée comme révélant un lien entre styles conversationnels et valeurs culturelles sous-jacentes.

Comme le fait également la pragmatique comparée en général, cette conclusion soulève des questions de représentation pour l'audiovisuel et la traduction audiovisuelle: comment les routines conversationnelles sont-elles projetées dans les dialogues de film et dans leurs traductions par le biais du sous-titrage ou du doublage? Quel est l'impact de ces représentations sur les spectateurs? Ces questions servent de base à une étude de cas qui s'attache dans cet article aux salutations et autres routines conversationnelles dans les sous-titres en anglais de trois films contemporains, deux en français, un en espagnol. Elles sont abordées dans une perspective de pragmatique comparée et avec pour toile de fond la théorie du mode de Fowler (1991, 2000), aux fins d'évaluer le potentiel textuel des sous-titres de film à signifier dans une perspective interculturelle.

\begin{abstract}
In a contrastive study of front door rituals between friends in Australia and France (Béal and Traverso 2010), the interactional practices observed in the corpus collected are shown to exhibit distinctive verbal and non-verbal features, despite similarities. The recurrence of these features is interpreted as evidence of a link between conversational style and underlying cultural values.

Like contrastive work in cross-cultural pragmatics more generally, this conclusion raises questions of representation from an audiovisual and audiovisual translation perspective: how are standard conversational routines depicted in film dialogues and in their translation in subtitling or dubbing? What are the implications of these textual representations for audiences? These questions serve as platform for the case study in this article, of greetings and other communicative rituals in a dataset of two French and one Spanish contemporary films and their subtitles in English. They are addressed from an interactional cross-cultural pragmatics perspective and draw on Fowler's Theory of Mode (1991, $2000)$ to assess subtitles' potential to mean cross-culturally as text.
\end{abstract}

\section{MOTS-CLÉS/KEYWORDS}

sous-titrage, pragmatique interculturelle, routines conversationnelles, représentation linguistique et culturelle

film subtitling, cross-cultural pragmatics, communicative routines, linguistic and cultural representation 


\section{Introduction}

In a 2010 contrastive study of front door rituals in social visits between friends in France and Australia, Béal and Traverso draw attention to conspicuous differences in interactional communicative practices in these contexts: exchanges are shown to exhibit distinct verbal and non-verbal features across the two settings, and to stand out linguistically and culturally despite similarities (e.g. to be more quickly expedited and matter-of-fact in the Australian data; see section 2). These recurrent differences in their corpus of naturally occurring verbal exchanges are interpreted as evidence of a link between conversational style and underlying cultural values.

This conclusion raises questions of representation from an audiovisual (AV) and audiovisual translation (AVT) perspective, as does contrastive work in pragmatics more generally: how are standard conversational routines represented intralingually in film dialogues and interlingually in their subtitles? And, relatedly, what responses do these linguistic representations trigger in audiences? The global dissemination of films and other AV products and the potential impact of what they convey of verbal practices on viewers' perceptions of otherness have made these questions increasingly critical.

They are addressed in this article from an interactional cross-cultural pragmatics perspective and against the background of Fowler's Theory of Mode discussed in earlier work (Guillot 2010; 2012a). Both are briefly recapitulated in the next section. Analyses then focus primarily on subtitles, where issues of linguistic representation are compounded by the specificities of the medium (speech-to-writing shift, space/ time/synchrony constraints). They apply to the subtitles in English of a dataset of two French and one Spanish films with, unusually, a good range of greetings sequences. This is revealing in itself and is discussed further in subsequent sections. The study is interested in subtitles' meaning potential as text, that is in subtitles' capacity to mean on their own terms, as a necessary step for developing a better understanding of their interplay with other meaning-making resources from the broader semiotic context (visual and from source dialogues, e.g. intonation, basic conversational turns easily recognizable across some languages like French and English, or in contexts of high multilingualism). Subtitles are not in practice processed in a semiotic or pragmatic vacuum, but this interplay of resources is very complex and it is beyond the scope of this paper to account for it in its intersemioticity and multimodality. Subtitles are thus approached independently as text, at least to begin with, so that their linguistic and pragmatic features can be assessed in their own right in the first instance, in line with the Theory of Mode and its focus on multimodality within text itself. The discussion confirms that subtitles have a capacity to generate their own sets of pragmatic settings, that deserve to be appraised in their own right as a tool in linguistic and cultural representation.

\section{Revisiting the Loss Argument - Pragmatic Deficits or Pragmatic Specificity?}

Features of language in use from a pragmatic and cross-cultural pragmatics perspective have received comparatively limited attention in AVT research. How subtitles represent and reflect how people talk and express interpersonal meaning - agree/ 
disagree, complain, apologize, etc. and conduct verbal negotiation across communicative settings - that is how language is used and meaning generated in social contexts, and the impact in this respect of differences in expectations based on cultural schemata (Yule 1996: 87; Senft 2014), has not figured very prominently on the research agenda, despite the topicality of attendant issues. The ever-growing global availability of films and other cultural products has intensified exposure to linguistic and cultural otherness mediated through the language of subtitling and dubbing. Their societal impact is potentially significant, but is as yet undetermined.

Hatim and Mason were pragmatics pioneers for AVT, and gave early momentum to research from this standpoint with their 1997 landmark study of politeness in subtitling. Others have followed suit, but few still and only relatively recently (Pinto 2010; Desilla 2009; Guillot 2007; 2010; 2012a for subtitling; Pavesi 2009a; 2009b; 2014 for dubbing, Bonsignori, Bruti et al. 2011; Bruti 2006; 2009a; 2009b for subtitling and dubbing). There are also incidental references to pragmatics in studies dealing with aspects of language use from other perspectives - with dialectal features, for example and strategies for conveying them inter-lingually in subtitling or dubbing (Ranzato 2010) or humour or orality (Romero Fresco 2006; 2009).

In studies with an acknowledged cross-cultural pragmatics outlook, features of verbal communication and communicative preferences are approached contrastively in dialogues and their subtitles, often with reference to questions of loss arguably illustrated in Examples (1) and (2) below. Both are dealt with out of their textual context at this point, as a preamble for reaffirming that loss is in fact relative, even at text-level alone, once the full textual context is taken into account and subtitles are considered as systems of signification in their own right, with a capacity to set their own pragmatic norms and conventions for representing communicative practices (see Guillot 2010; 2012a). This is the stance that underpins discussion in this paper and its main focus for the purpose of argument. Subtitles' potential to mean is also a function of their multiple contextual embeddedness. For reasons of space, their interaction with other semiotic resources can only be broached tangentially here.

In the examples used, numbers on the left-hand side refer to subtitle lines or groups, and arrows point to text drawn to particular attention in the discussion. Source dialogues and gloss, where included, are shown below or next to subtitles as $[\mathrm{SD}]$ and $[\mathrm{BT}]$ (back translation) respectively. Dialogues are transcribed using standard conventions for speech, with no punctuation or capitalization, but breaks between tonal groups (/). Subtitles' number references are shown in square brackets in the discussion, e.g. as [1] and [2] for subtitles in examples (1) below.

In Example (1) the setting is the office of George Laurent, the main character in the film Caché (Haneke 2005), the speakers are George (G) and his personal assistant (PA), at [2] and [1] below respectively. 
EXAMPLE 1

Source dialogues, subtitles and back translation in Caché

\begin{tabular}{|l|l|l|}
\hline Source Dialogue & Subtitles [SD] & Back Translation [BT] \\
\hline (G) bonjour/ & & Good morning \\
\hline $\begin{array}{l}\text { (PA) bonjour monsieur/ } \\
\text { je viens juste d'avoir votre femme/ } \\
\text { elle vous demande de la rappeler/ }\end{array}$ & $\begin{array}{l}\text { Your wife called. } \\
\text { Can you call her back? }\end{array}$ & $\begin{array}{l}\text { Good morning sir } \\
\text { I've just had your wife } \\
\text { she asks you to call her back }\end{array}$ \\
\hline (G) Ah bon merci & OK, thank you. & Ah good thank you \\
\hline
\end{tabular}

The setting for Example (2) is a staff meeting with one expected attendee missing (Le Henry), the speaker is a company manager addressing his personal assistant (PA), Carla Behm, main character in the film Sur mes lèvres (Audiard 2001)1 (also discussed in Guillot 2010; 2012a).

EXAMPLE 2

Source dialogues, subtitles and back translation in Sur mes lèvres

\begin{tabular}{|l|l|l|}
\hline Source Dialogue & Subtitles [SD] & Back Translation [BT] \\
\hline $\begin{array}{l}\text { Carla / je vous demandais } \\
\text { où était Le Henry/ }\end{array}$ & Carla? Where's Le Henry? & $\begin{array}{l}\text { Carla I was asking you } \\
\text { where Le Henry was }\end{array}$ \\
& $\begin{array}{l}\text { (vs. e.g. Miss Behm, where's Le Henry } \\
\text { [title+surname, comma] } \\
\text { Miss Behm where's Le Henry [title+surname, } \\
\text { no comma] } \\
\text { Where's Le Henry [no term of address, max. } \\
\text { directness]) }\end{array}$ & \\
\hline
\end{tabular}

In Example (1), the telephone exchange depicted in the subtitles is reduced to the bare bone of what is necessary to take the narrative of the film forward: the caller is shown to go straight to the object of the call, with no opening move or greeting, and minimal acknowledgement from the interlocutor. The linguistic and pragmatic abruptness of the exchange is echoed in the directness in form of the request for information in Example (2) (Where's Le Henry), a face threatening act normally mitigated with toning down features in the language of the subtitle - English (for instance, with modal verbs, politeness markers, as in could you please tell me where so and so is..., and documented in politeness theory; see Brown and Levinson 1987). The implications of the cultural mismatch between the (English) language of the subtitle, what is normally expected from it in terms of communicative preferences and what is heard and seen on screen, for example French native speakers in a French setting, have been drawn to attention in earlier work with reference to this concisely illustrative second example (Guillot 2012a). The propositional content and perlocutionary intent of the utterance, that is its basic meaning and intended consequence, are essentially the same in the source dialogue line in French and the subtitle in English: both reiterate an earlier request for information about a third party's whereabouts. Their form is substantially different, however. From Carla/ je vous demandais où étais Le Henry/ [Carla/ I was asking you where Le Henry was/] in the source dialogue to Carla? Where's Le Henry in the subtitle, there is a conspicuous shift from a (heavily) mitigated request to an unmitigated request (indirect vs. direct form of 
the request, tense shift). The directness projected in the subtitle if it is taken at its face value in this restricted context belies the source dialogue line. It also raises questions about the potentially negative perception of communicative practices in French that may be promoted for native speakers of English, especially in relation to standard stereotypes about national linguistic characteristics (directness/rudeness of the French or German, for example, as discussed in House 2005 or Kerbrat-Orecchioni 2005; Pinto 2010 also makes related observations about the advice speech act in Spanish-to-English subtitles). In both examples, there is a cultural and pragmatic mismatch that is problematic: it appears to make room for a loss argument, resulting from the co-presence of a visual and aural component associated with a particular language or culture, and written text in another language for which expectations may be different, notably in terms of politeness, modes of address or other standard face threatening practices like complaints, disagreements, etc.

Things look quite different when the broader prior context is taken into account. It helps counter the loss argument with a more positive spin on (inevitable) textual reduction, by highlighting the potential of subtitles to generate their own sets of pragmatic settings and work as systems of multi-modal representation in themselves. In Example (1), the pragmatic bareness of the subtitles is sanctioned by the pragmatic conventions established earlier on in the same film, as will be shown below, and the thank you [2] is a critical anaphoric trigger that retrospectively precludes the bareness being interpreted as rude. In Example (2), the use of the Christian name Carla as a term of address is marked and stands out at this point: it is a shift from the title+surname Mademoiselle Behm [Miss Behm] that had been used up till then by the same locutor, Carla's boss, and that is normally the expected distance-keeping default mode of address in a work context for their boss/PA relationship in a French context. The interpersonal empathy produced by the shift to the Christian name primes the request as non-threatening despite the absence of moderating features. The argument is underpinned by Fowler's cognitively-driven Theory of Mode (1991, 2000), originating in Fowler's interest in multimodality within text itself. The theory was put forward to account for orality in written text, i.e. in text intended to produce the illusion of speech, and proposes that "language texts can be multimodal in the sense that the oral can exist within the written," "that there may be traces of written in the oral" (Fowler 2000: 32). Its principles are a simple heuristic for dealing with other aspects of text, however, and for accounting for the pragmatic impact of subtitles. For Fowler, all that is needed for a written text to be experienced as speech, given our inbuilt competence to recognise speech from writing, is a few cues or triggers of orality (e.g. parataxis, marked modals, deixis, prominence of first and second person pronouns, of speech acts like questions and command suggesting a direct relationship with the reader and a dialogic structure, typography, etc., as in Hurry and order now while stocks last! (2000: 34), or Order NOW!, for example). An important proviso is that cues should work together in an integrated way, i.e. should not be random. Again, as shown in earlier work (Guillot 2008; 2012a), punctuation in Example (2) is a case in point in the application of the theory to AVT and the pragmatics of subtitles: the question mark after Carla flags a rising intonation denoting caring tentativeness in the prompt for attention, and creates a pause that pre-mitigates the request and pre-tones it down: it is overtly direct in form, but its perlocutionary impact is not. Terms of address and punctuation work together in triggering response 
modes that deflect from taking the direct form of the request at its face value, and from being projected as literally representing communicative practices in the source language. The alternatives shown in italics in brackets in Example (2) give a measure of the cognitive and pragmatic impact of different choices of form for the same propositional content.

In (1) the textual trigger affecting pragmatic perception and response is thank you, as noted. The example is considered further in the discussion below. It will be used with the platform of the Theory of Mode and earlier work to explore further the relationship there may or may not be between representations of conversational practices and accounts of pragmatic cultural distinctiveness in cross-cultural pragmatics, like Béal and Traverso's.

In Béal and Traverso's (2010) contrastive analysis of crossing-the-threshold exchanges from an interactional perspective, three main constitutive elements are identified: greetings, miscellaneous comments (e.g. about the setting, arrival time), laughter. The main difference across French and Australian English appears to be that various steps take longer in the French data. Greetings are shown to be performed in one step in Australian English (e.g. hi or hi how are you in one step), as against two or more in French (e.g. salut [hi], then ça va [how are you] then kisses). They give the impression that the greeting ritual is speedier and more matter of fact in the Australian corpus, with also a different overall tone. The findings echo observations from other studies by Béal, about responses to the question Did you have a good week-end (1992), for example, shown to elicit far more extended rejoinders in French than in Australian in work contexts (see also Béal 2010). These macro level differences in the overall structure of conversational routines find an echo at micro level in the linguistic design of speech acts (Béal 2010), for example. Findings in these studies are quite broad overall, but still raise key questions: about the extent to which distinguishing features of standard conversational routines are observed in their (written-to-be-spoken) textual representations in film dialogues, and in their subtitles; and about the picture that is conveyed in both of the verbal habits in source contexts and languages. In subtitles, text is twice removed from naturally occurring speech, taken back again from the artefactual speech of source dialogues to writing, and subject to space and time constraints in the interlingual shift, so the issue is particularly complex.

Greetings have been considered in dubbing. Bonsignori, Bruti et al. (2011) deal with leave takings and good wishes, for example, but as keys to orality rather than from the perspective of representation. The study is based on a corpus of 9 films dubbed from British and US English into Italian and three Italian productions and draws attention to various qualitative asymmetries. It shows that discrepancies in linguistic mapping across languages result in socio-pragmatic shifts, neutralisation or omissions. Examples include shifts from one-time expression to another (for example, buongiorno [good day] to good morning), from phatic expressions to vocatives (for example, signora [madam] to how are you), omission of generic terms with no single equivalent in Italian like mate, and what is described as stylistic variations on greetings terms like hello, hi, hey in English, ciao, salve, ehi, buongiorno in Italian. On the other hand, frequency counts of these frequent (and other) greeting terms are shown to coincide in the dubbed and Italian films in the corpus. The research overall shows that films dubbed in Italian and actual Italian films converge in their depiction of greetings and leave takings, and confirms these features as keys 
to orality in both. It notes in its conclusion that greetings and leave takings are given significant space in English film language and dubbed Italian, and that their congruent mapping is accordingly very important. There is no comparison with naturally occurring speech.

In subtitling, patterns of alignments and misalignments are governed by different factors and produce different kinds of observations. These may give cause to review analyses for dubbing in the light of additional factors, and in particular reassess the relationship with naturally occurring speech.

\section{Data, Methodology, Research Focus}

It is a challenge to collect naturally occurring interactional data of the type used by Béal and Traverso in their cross-cultural pragmatics research, and their kinds of studies are rare as a consequence, for French and most other languages (recording greetings and most types of verbal interactions in social contexts is logistically problematic, as is ensuring that interactions are authentic in content and form if recording is carried out with participants' knowledge, or to avoid ethical issues if not).

It is also difficult to collect film dialogue data for comparison but for different reasons, relating to the nature of film dialogues. It is routinely noted in AV research that film dialogues are not naturally-occurring speech, but written to be spoken for the benefit of an overhearing audience, with an unescapable drive to take a narrative forward while keeping audiences in the loop. They must be maximally efficient, and mostly have no space for phatic chit-chat or routinized exchanges like greetings, for example, unless these have a function for the narrative. In that case they are adapted to fulfill this function (as examples discussed below will confirm). Friends' social or other types of visits in films are never just friends' social visits, but are always marked in some way, and there are few in any case, as viewing films to collect data for this kind of study confirms. Their paucity and the paucity of phatic sequences in films is in itself an index of the artefactual nature of film language. Bonsignori, Bruti et al.'s point about their prominence in films may thus need to be relativized, and subordinated to function.

To generate more usable data for the study, the focus of the enquiry was extended beyond front door rituals in friends' social visits, and Béal and Traverso's study was used as a basic canvas to set up the research and identify questions. The study also encompasses greeting sequences more generally, and leave-taking and telephone exchanges, in two near contemporary French and one Spanish films: Paris (Klapish, 2008) ${ }^{2}$ and Hidden (Caché) (Haneke, 2005) ${ }^{3}$ for French, and Volver (Almodóvar 2006) ${ }^{4}$ for Spanish. All three feature several greeting/phone/exchanges/leave taking scenes, uncharacteristically, and that was a main criterion for selection. They are still few, but make it possible to observe possible patterns or features of representation across sets, both internally within each film and across all three films. Some of these greeting/phone exchanges/leave taking scenes include corresponding verbal routines, some do not. Those that do not are significant for the discussion, as will be shown in the next section, and form part of the overall data. The Spanish film was included to test observations about representation and the principles discussed from the perspective of another language; conversational conventions are not assumed to be the same in the two source cultures featured. 
Paris follows the intersecting lives of various characters over a short period of time, in a psychological and sociological bird's eye view of types of people in a particular place at a particular time. Hidden is also sociocultural and psychological, but a thriller with historico-political roots: the main character is harassed by an unknown party with postings of videos of his everyday life and offensive drawings relating to his past and the conflicts he embodies. Volver is likewise a kind of sociocultural portrait of a community of women, their traditions, beliefs, historical legacies.

The study is dealt with as a case study. The subtitle data are analysed first, so that they can be assessed on their own terms in the first instance, with source dialogues or naturally occurring speech practices used to supplement observations, as in earlier work (Guillot 2012a; 2012b). The discussion also applies to subtitles at the level of text primarily, to trace their potential as a meaning resource in itself, as a necessary step for assessing it in its interplay with other semiotic resources.

The argument and conclusions relate to three main aspects, addressed in turn in section 4 below: the linguistic fiction of subtitles (4.1.), their linguistic and pragmatic situatedness (4.2.), patterns of linguistic and cultural representation and subtitles' potential for sensitization to linguistic and cultural otherness (4.3.). The main points explored are as follows:

i) to what extent can naturally occurring speech guide analyses of audiovisual text, and film subtitles specifically?

ii) if subtitles are linguistic make-belief, as analyses in (4.1.) will confirm, looking for matches and verisimilitude in relation to naturally occurring speech is of limited interest. Yet subtitles are still harnessed, via target texts, to source texts and to naturally occurring verbal interactions. What is, then, the relationship between these three related but distinct manifestations of language use? This is a core issue in AVT cross-cultural pragmatic research, and the main question in this case study. The focus at this stage is on subtitles as a medium of expression and representation as text, and thus on the extent to which, as text, they can generate their own pragmatic conventions for representing verbal routines, as situated practices, for example, that is practices set internally.

iii) if subtitles have a capacity to set their own internal pragmatic conventions and settings, as argued in (4.2.), what kinds of representations are conveyed textually? Are recognizable patterns in evidence in the data, of the type identified in Béal and Traverso, for example, and what is their potential to cue linguistic and cultural otherness, for example, give a sense that conversational practices may not be the same in the source language represented via the target language for the linguistic and cultural context shown on screen?

A further question would relate to translation quality, namely the quality of the sample subtitle material in this particular case study, and quality in subtitles more generally, from the cross-cultural pragmatics and representational perspective used here: how representative of subtitlers' practices can the sample considered here be deemed to be? This is a much broader question that cannot be handled here. Dealing with it will entail building up a much larger body of evidence than is currently available and cataloguing patterns in representational practices on a much larger scale, a critical step for further research in this domain. 


\section{Subtitles' Fictions, Pragmatic Conventions and Stylized Representation}

\subsection{Linguistic Make-belief of Subtitles - The Proof of Greeting Sequences}

In the five examples analysed below, from Paris (Klapish 2008) in (3), (4), (5), Volver (Almodóvar 2006) in (6) and Caché (Haneke 2005) in (7), greeting sequences are in evidence to different degrees and in different forms. That is the rationale for selecting them for discussion. They are used here to demonstrate the extent to which greetings or other similar types of standard verbal routines in subtitles and in sources dialogues are subordinated to other functions when present at all, and linguistically manipulated to this end.

In the subtitles in Example (3) from Paris (Klapish 2008), of a front door scene showing a character visiting his brother (B2 and B1 respectively below), there are no greetings at all (and none in the corresponding source dialogue): the text cuts straight to the narrative focus of the scene (an unexpected visit and extravagant present - a painting - to the visited brother (B1), flagging a psychological shift in the visiting brother (B2)). There is no need for standard early greeting moves in the scene, pragmatically or otherwise, they are taken as read and left out.

Example (3) subtitles in Paris

\begin{tabular}{|l|l|}
\hline Source Dialogue & Subtitles [SD] \\
\hline qu'est-ce que tu fais là/ & B1 What are you doing here? \\
\hline je t'ai apporté ça/ & B2 I brought you this. \\
\hline qu'est-ce qu c'est/ & B1 What is it? \\
\hline c'est ce que tu as devant ta fenêtre/ & B2 The view from your window. \\
\hline t'es complètement dingue/ & B1 You're completely nuts \\
\hline
\end{tabular}

The two scenes in Examples (4) and (5), also from Paris, show that greeting moves are otherwise in evidence in the film, but principally as a canvas for the narrative to progress. In the market stall scene of Example (4), the greetings serve to set up the line in subtitle [10], a key line in the scene, by the stall holder (SH)'s daughter Lauryn (L) (Simone is the one who doesn't know her father): the line exposes the market stall female customer (C) speaking in subtitles [3] and [8] as a single mother, and at an emotional loss by association; it is overheard by a second (male) stall holder and heralds what later develops into a relationship between these two protagonists. It needs to be brought on, however, contextualised, and the (- Hi. / - Hi, Lauryn/How are you etc.) greeting canvas [3-4] fulfils this function. In Example (5), set in/outside a bakery, the greeting canvas serves to contrast two facets of the same character, a female baker, with her victimization of the trainee employee she is guiding in setting up a window display (seen and patronizingly addressed in subtitles [2] to [6] and [8], but not heard) and her assumed affability for everyone else (seen in her exclamatory hellos in subtitles [1] and [7] and health-relating enquiry in [7] (Feeling better?, both to passers-by). ${ }^{5}$ 
(4) [Subtitles] [12.17]

$$
\begin{array}{ccc} 
& {[\ldots]} & \\
3 & \mathrm{~L} & - \text { Hi. } \\
& \mathrm{C} & - \text { Hi Lauryn } \\
4 & & \text { How are you? } \\
5 & & \text { Oh, you're Lauryn's mom? } \\
6 & & \text { I'm Simone's mom } \\
7 & & \text { I saw you at school } \\
8 & \text { SH } & \text { Oh, yeah! Right, Simone. } \\
9 & & \text { Lauryn's always talking about you. } \\
10 & \mathrm{~L} & \text { Simone is the one } \\
& \multicolumn{4}{l}{\text { who doesn't know her father. }} \\
11 & \text { SH } & \text { Yes. You told me that. } \\
12 & \mathrm{C} & \text { So, I'll take a kilo of apples. } \\
13 & \text { SH } & \text { Okay, a kilo of apples! } \\
{[. . .]} &
\end{array}
$$

(Paris; Klapish, 2008)

(5) [Subtitles] [5.16]

$$
\begin{aligned}
& \rightarrow 1 \text { B Hello! } \\
& 2 \text { There! Now the mushrooms. } \\
& 3 \text { That's what makes it look } \\
& \text { like autumn. } \\
& \text { I don't want to see... } \\
& \text { What a ninny! Unbelievable! } \\
& \text { There! } \\
& \text { Now fan out the bouquet a little. } \\
& \rightarrow 7 \quad-\text { Hello! Feeling better? } \\
& \text { PB - Yes, thank you. } \\
& 8 \text { Solène, you had a customer! [...] }
\end{aligned}
$$

(Paris; Klapish, 2008)

Example (6) from Volver confirms greetings as a critical site for setting up or developing narratives, and the make-believe nature of the exchanges that enact them. It is set in the local cemetery/graveside and involve Agustina (A), on her way to clean her family's grave and, from [2], her (main character) friend Raimunda (R), with daughter Paula (P); cleaning family graves is an annual event that brings local women together in the cemetery, on that occasion a windy day. Here in the opening scene of the film, greetings are a canvas for introducing three lines that foretell the story and provide critical cues for later: she's got your father's eyes [5]) flags that the father of the girl referred to will turn out to be her mother's father; not good [6] in response to an enquiry about well-being flags that the character speaking (Agustina) will turn out to have cancer; With this wind, you can't keep it [a grave] clean [9] is a reference to the same [East] wind that precipitated some time before the tragedy that is a core feature in the film. The opening Hello is addressed to characters passed by on the way to the site of the subsequent exchange starting at line [2], for which it serves as 
an implicit first turn. It is also a cue that standard phatic opening routines are adhered to even when not present. It makes them henceforth surplus to requirement unless narratively instrumental, like the next sets of ritual exchange adjacency pairs here, from [2] through to [3] [Good Lord!/Is this Paula?/Of course]: these are the necessary lead-on for the She's all grown up! line in [3] that warrants the comment about the girl's eyes.

(6) [Subtitles] [1.50]

\begin{tabular}{|c|c|c|c|c|}
\hline & 1 & A & Hello & (to women on the way towards her family grave) \\
\hline & 2 & $\mathrm{R}$ & - This is wonderful! & \\
\hline & & A & - Good Lord! & \\
\hline & 3 & A & - Is this Paula & \\
\hline & & $\mathrm{R}$ & - Of course. & \\
\hline & 4 & A & She's all grown up! & \\
\hline & & $\mathrm{R}$ & - Give her a kiss. & \\
\hline$\rightarrow$ & 5 & A & She's got your father's eyes. & $\begin{array}{l}=>\text { the father of the girl turns out to be her } \\
\text { mother's father }\end{array}$ \\
\hline & 6 & $\mathrm{R}$ & - How are you? & \\
\hline$\rightarrow$ & & A & - Not good. & $\begin{array}{l}\Rightarrow>\text { the character is revealed to have cancer } \\
\text { later on. }\end{array}$ \\
\hline & 7 & $\mathrm{R}$ & Don't say that. & \\
\hline & 8 & A & $\begin{array}{l}\text { I want to give my grave } \\
\text { the once over. }\end{array}$ & \\
\hline$\rightarrow$ & 9 & & With this wind, & $\begin{array}{l}\Rightarrow>\text { the same (East) wind precipitated some } \\
\text { time before the }\end{array}$ \\
\hline
\end{tabular}

(Volver, Almodóvar, 2006)

In contrast with all previous examples, the greeting sequence shown in table form in Example (7) from Hidden is protracted in the extreme. There are no opening greeting moves between the protagonists, George the main character in the film $(G)$ and his TV boss/hierarchical superior (B), who has summoned George to his office, i.e. there is no exchange of greeting terms like hello or good morning. But there are five question/answer adjacency pairs and a staggering 20 lines of subtitle of ritual greeting enquiries about life, family etc. and offer of coffee, before the object of the exchange is cut to the chase, in the character's words [15] (second of the three columns in Example (7)); each column marks a different phase in the exchange and they are shown side by side for ease of comparison; textual transitions between them are underlined). The real motive of the meeting summon is only finally revealed another 18 lines later [ 31 and subsequent] ( $3^{\text {rd }}$ column). As will be shown below, the civilities included at the onset of the exchange are normally dispensed with as assumed, or set up to be assumed. Their occurrence and extent thus has a blatant suspense-building function for the audience. It signals from the start that something is amiss, and generates a double helping of tension with the stacking up of two motives for the summon: the first is a work-related matter that is plausible and significant in its own right, but it works as a decoy for the real second one, a blackmailing videotape incriminating George. 
(7) [Subtitles] [1.01]

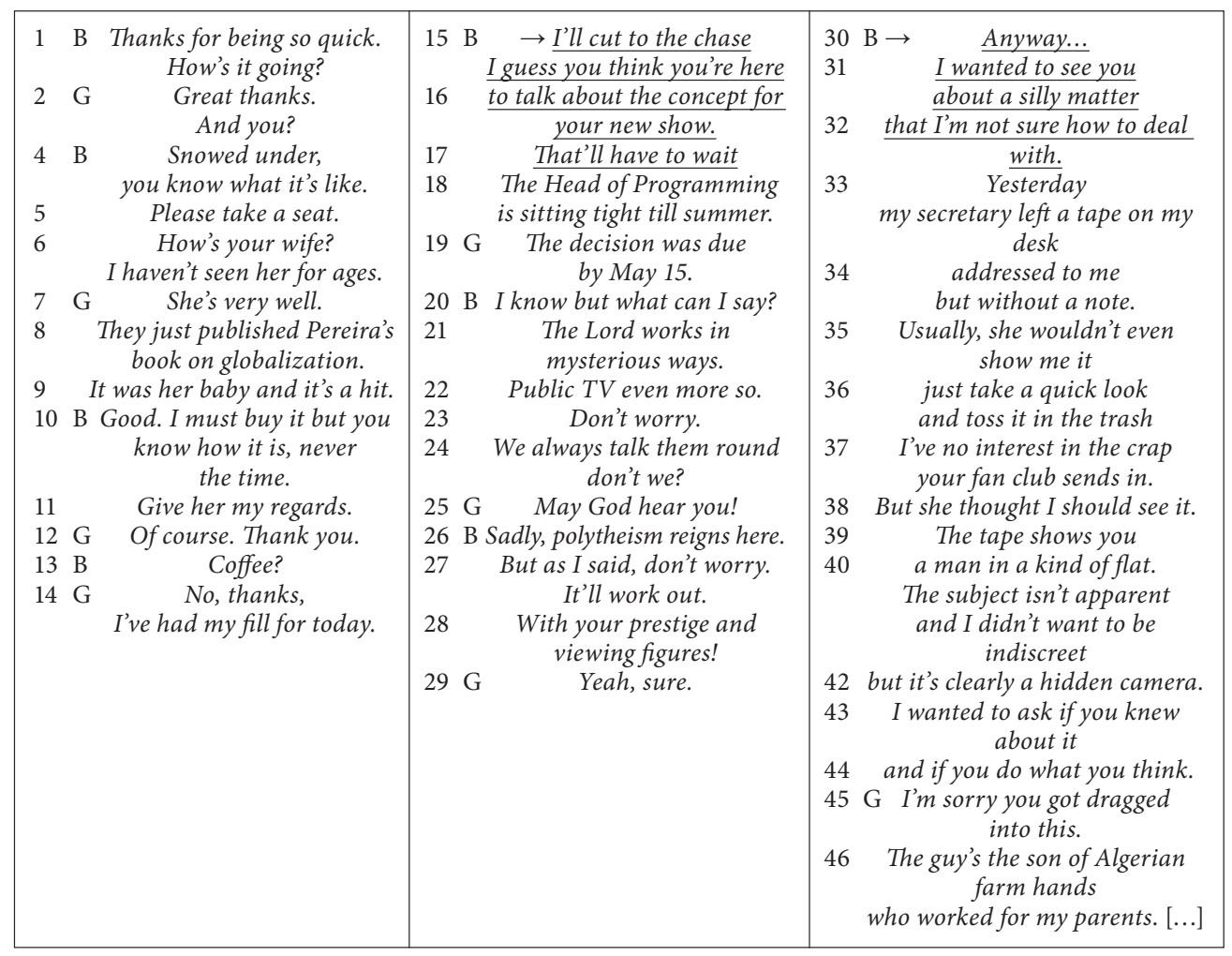

(Caché/Hidden; Haneke 2005)

These contrasting examples are striking evidence of the extent to which greeting sequences are harnessed to narrative needs, and linguistically adapted to fulfil these needs. They are highly stylized, a (more or less distant) echo of greeting routines discussed in pragmatics research or conversation analysis. This applies to other types of conversational routines, like telephone calls, used in the next section to broach the notion of film language pragmatic situatedness, namely setting of internal pragmatic conventions and practices.

\subsection{Pragmatic Situatedness and Linguistic Indexing in AV Contexts}

\subsubsection{Situatedness}

Pragmatic situatedness is understood here as relating to subtitles' capacity to evolve their own conventions for representing verbal routines, and set up their own internal pragmatic settings. It was alluded to in example (1) above, and is illustrated in the sequence of three telephone calls in example (8), all from Caché/Hidden, and in the different kinds of responses they promote in terms of politeness. The exchanges are presented in their order of occurrence in the film (15.04, 15.23 and 15.44 minutes from the beginning respectively), and show how internal conventional representations are set up and manipulated, and how they evolve. The three exchanges are 
shown side by side to highlight contrasts between them. The speakers for the first two exchanges are the wife of the main character (George Laurent) (W), and a) one of George's work colleagues (M) at [15.04], and b) George's blackmailer (B) at [15.23]; the third exchange at [15.44] is Example (1) introduced earlier and involves George (G) and his PA (P), at work.

(8) [Subtitles]

$$
\begin{gathered}
\text { [15.04] } \\
1 \mathrm{M} \quad \text { Mrs Laurent? } \\
2 \mathrm{M} \quad \text { Hi, this is Manu. } \\
\text { Is George there? } \\
3 \mathrm{~W} \quad \text { You missed him } \\
\text { by a couple of minutes. Sorry. } \\
4 \mathrm{MIt} \text { was to remind him about } \\
\text { the Beaumont file. } \\
5 \mathrm{~W} \text { He took it. I saw him. } \\
6 \mathrm{M} \quad \text { Great. Thank you. } \\
\text { Have a good day! } \\
7 \mathrm{~W} \quad \text { Bye, Manu. } \\
\quad \text { (42 words) }
\end{gathered}
$$

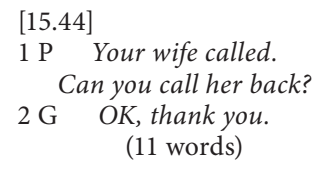

[SD]

allo oui/ ... oui

bonjour c'est Manu/ Georges est encore là/ bonjour non il vient de partir y a deux minutes/désolée

d'accord c'est pas grave/j'voulais juste lui rappeler de pas oublier le dossier Baumont / ah il l'a pris/je l'ai vu/

très bien/merci/bonne journée/au revoir/ au revoir Manu/au revoir / (59 words)

(Caché/Hidden; Haneke 2005) oui/

j'voudrais parler à George Laurent/ oui/qui est à l'appareil? j’voudrais parler à George Laurent/ oui qui êtes-vous/qu'est- ce que vous voulez/ je voudrais parler à celui qui s'appelle George Laurent/(37 words) bonjour/

bonjour monsieur/je viens/ juste d'avoir votre femme/ elle vous demande de la rappeler / ah bon merci/ (19 words)

The first exchange at [15.04] is pragmatically bare in form, but responded to as pragmatically in line with politeness expectations in the on-screen interaction. The unmitigated address without any kind of other phatic preamble (Mrs Laurent) [1], and the unmitigated request for information Is George here [2] are both seemingly out of line with prototypical practices. This is also the case of subsequent more or less face-threatening assertions by both parties in the exchange, all likewise unmitigated (compare with e.g. Oh hello Mrs Laurent / Could you please tell me if George is there?). There are several cues that prevent the text from being taken at its face value, however, and the exchange projected as face-threatening. The Christian name Manu used by the caller to introduce himself in Hi, this is Manu. [2] establishes that he is already known to his interlocutor (Mrs Laurent). The informal register of $\mathrm{Hi}$ that is used despite the difference in status manifest in the surname/name asymmetry (Mrs Laurent/Manu) concurrently suggests that politeness rules have already been negotiated down at some point prior to this exchange, even though the audience has not been a party to the negotiation. The request and the exchange as a whole are responded to positively by both exchange parties: the interlocutor accedes to the request, and the symmetrically affable leave-taking adjacency pair at the end of the call confirms that politeness rules are not considered to have been violated from the perspective of the characters on screen (Great. Thank you. Have a good day! / Bye, 
Manu.) [6]. Critically, the non-essential Christian name Manu at the close of the call in Bye, Manu. and the deliberation in using it that the comma produces retrospectively confirm that and sanctions the (formal) pragmatic starkness of the exchange (compare with Bye. or with Bye Manu.). Given the significant reduction in the text of the subtitles (see below), retention of a lexical item that could have been omitted is noteworthy, and works here as a cue to the (positive) pragmatic value of the exchange.

Once conventions are set up, as they are with this first phone interaction, they (can) get streamlined, and rely on minimal triggers to cue apposite responses, for the characters on screen, and for the audience. The exchange at [15.44] (also Example (1)) is reduced to the very bare pragmatic minimum, as noted earlier, but the closing and here again non-essential thank you in Ok. Thank you, confirm that it is oriented to positively and shown to be experienced as not violating any politeness rule. It is an echo of the Manu cue above. As if it is enough to signpost pragmatic appropriacy.

Conversely, non-adherence to the conventions set up flag exchanges as marked and makes them stand out. In the exchange at [15.23], the request (I'd like to speak to George Laurent) [1] is mitigated and conspicuous as a consequence: it contrasts with the practices of keeping formal politeness features to the minimum evidenced in prior exchanges, that are otherwise adhered to here with the omission of opening phatic moves. The directness of the interlocutor's call for identification just after (Who is this?) [2] suggests that the request is responded to as out of line with expectations, and is suspect. The subsequent full word-for-word repetition and third reiteration of the request in further spelled-out form $[3,5]$ are all unusual in view of subtitling constraints, they confirm it as marked, and confirm the orientation of the interlocutor, escalated in another set of paratactic direct questions (Who are you? What do you want?) [4].

As ever, the text of the subtitles is a reduced version of source dialogue texts. As intralingual representations of naturally occurring speech, source dialogues are themselves stylized by comparison. All the same, all three examples in their source dialogue version do include a greeting frame that displays standard adjacency pairs of natural speech, i.e. allo oui...oui// bonjour in the first at [15.04], oui// in the second at [15.23] (with omission of the second pair part, denoting politeness violation), bonjour//bonjour monsieur in the third at [15.44]. They also feature conspicuous mitigation of face-threatening speech events and indirectness by comparison with subtitles. By comparison with j'voulais juste lui rappeler de pas oublier le dossier Baumont in the first source dialogue exchange at [15.04] [I just wanted to remind him not to forget the Baumont dossier], the corresponding subtitle It was to remind him about the Baumont file is barely mitigated: the shift from the $1^{\text {st }}$ to the $3^{\text {rd }}$ person is impersonal, there is omission of the downtoner just, and a shift from an indirect negative verbal phrase to a direct affirmative prepositional phrase. In the third exchange at [15.44], je viens juste d'avoir votre femme/ elle vous demande de la rappeler in the source dialogue [I have just had your wife / she is asking you to call her back] is also less direct than the corresponding subtitle Your wife called. Can you call her back? where there is omission of mitigating downtoners and a shift from an indirectly reported to a direct unmitigated request, albeit expressed as a question. The features of politeness in evidence in the sources dialogues are thus only selectively and minimally integrated into the subtitles, as these examples show. Those present 
can arguably fulfil similar pragmatic functions, however, by dint of the parameter setting just discussed. Significantly, the exchange that shows the least reduction and stands out in the set is the second [15.23], i.e. the exchange that is in breach of the conventions set up and flagged as denoting impoliteness (8\% reduction (from 40 to 37 words), as against almost $30 \%$ and $58 \%$ for the first [15.04] and third [15.44] exchanges (from 59 to 42 words and 19 to 11 words respectively): what should not be taken as read as conventionally set up requires greater explication.

This set of pragmatically inter-related examples confirms that subtitles have a capacity to generate their own internal pragmatic settings for verbal exchanges, and to capitalise on contrasts generated internally. That politeness practices are adhered to is established and set up as assumed early on. It is subsequently confirmed by only minimal triggers. Deviations from these internally set and highly stylized practices show as marked, and contrasts highlight their narrative significance. This pragmatic situatedness and internal setting is manifest in other features. It is further illustrated below with the pragmatic indexing of $\mathrm{Hi} / \mathrm{Hello}$ in the subtitle data, where each of these greeting terms is allocated a particular pragmatic value, distinct from the values shown in the dialogues. Questions of representation are taken up in the subsequent section.

\subsubsection{Pragmatic and Linguistic Indexing: Subtitle vs. Source Dialogue Conventions}

Indexing refers here to the particular pragmatic values assigned to particular terms in the dialogue and subtitle data, in this instance greeting terms.

There are few occurrences of greeting terms in the subtitle data: 7 in total in Caché, 10 in Paris, 8 in Volver. The foregoing discussion has made clear why. There are also only two different terms, $h i$ and hello (with the exception of one hey in Volver), so here again a degree of stylization which is confirmed in the pragmatic indexing observed in the data, different in nature across the three films in the dataset.

All occurrences of greetings terms in all three films in the dataset are shown in Table 1, in separate columns, one for each film, with corresponding source dialogue text (underlined for French and in bold italics for Spanish).

In Caché (Haneke 2005) hi dominates and is used in all but one of the 7 instances of greeting terms in the film, in each case in the context of encounters of a nonformal nature between adults, with one instance of an adult/child (father/son) exchange. There is just one occurrence of hello in Hello, Yves. in a child/adult telephone exchange that stands out as marked by contrast (double-underlined in Table 1, column I [1.09]). It corresponds to a dramatic turn of events (disappearance of the caller's son; Yves, the son's friend, is the last one to have seen him and is about to be asked about this). The shift to hello has little to do with rapport, and appears instead to signal for the young boy the seriousness of the situation and for the audience the anxiety of the caller, the missing boy's mother. An early error in the transcription, Hello Yves with no comma, shows how punctuation can affect perceptions and responses, and be part and parcel of pragmatic indexing. The example would have been the only one in the set where the greeting term was not followed by a comma, significantly. This omission would have marked a shift of focus from the greeting as an end in itself, as in Hi, Pierrot. (Table 1, column I [18.11]), to the greeting as a preamble for a next move and a call for attention which, too, would have pointed to and reinforced the seriousness of events. 
TABLE 1

Greeting terms in context in the three films of the subtitles data set

\begin{tabular}{|c|c|c|}
\hline (6 hi, 1 hello) & (4 hi, 6 hello) & III Volver ( 3 hi, 4 hello, 1 hey) \\
\hline 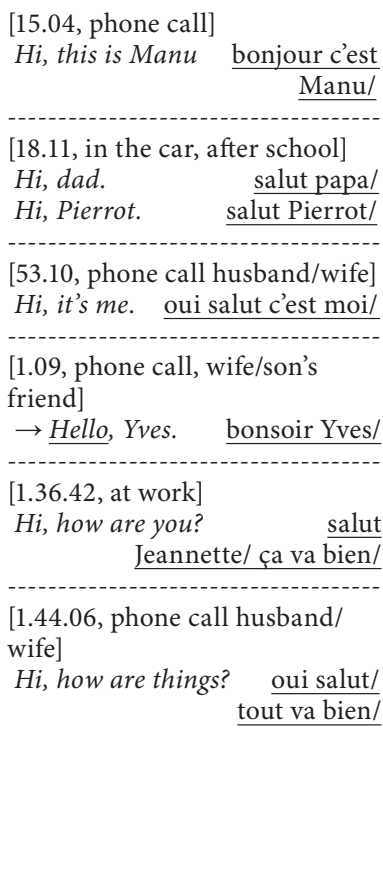 & 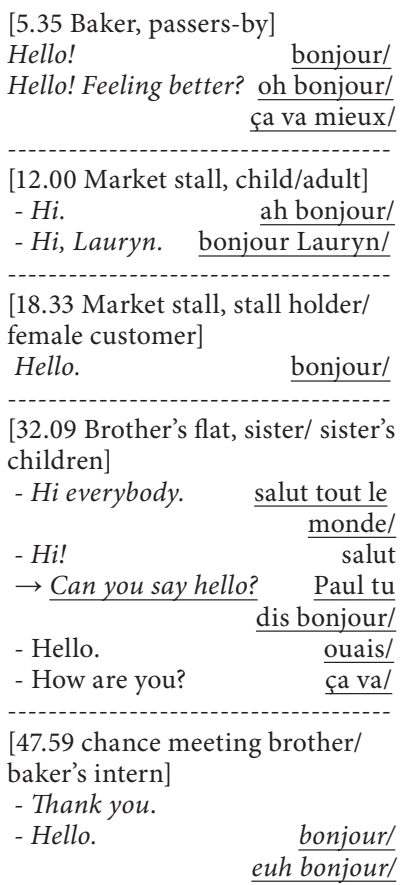 & 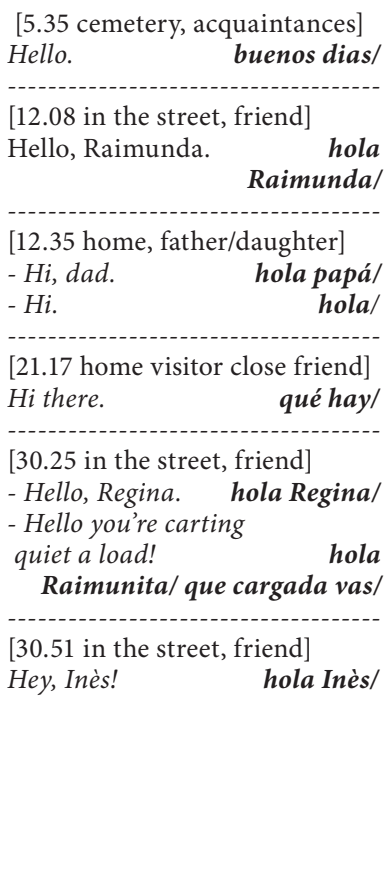 \\
\hline
\end{tabular}

In Paris (Klapish 2008), the hi/hello interplay appears to mark degrees of familiarity, i.e. rapport in this case: $h i$ is used where children are involved and within family (in 4 of the 10 occurrences of greeting terms), hello is used for more distant relationships (e.g. baker/ passers-by in Table 1, column II [5.35]) (5/10 cases). There is one marked exception where hello is used with a child, to make a point and remind him to conform to politeness practices (in bold in Table 1, column II [32.09]). It is set against $h i$ to this end. The same type of pragmatic values and indexing of rapport seems to apply in Volver (Almodóvar 2006), where it is possibly reinforced by contextual factors (home vs. outside).

This kind of pragmatic indexing is also in evidence in the source dialogues in all three films, but there is no one-to-one matching indexing relationship between source dialogues and subtitle text: the pragmatic value assigned to the greetings is different. The absence of correspondence confirms that subtitles evolve their own settings independently, to some extent at least: in Paris Klapish 2008), for example, bonjour a standard and unmarked greeting term alternates with the more informal salut used in the film exclusively with family, in a distribution which does not coincide with the distribution and indexing described above for subtitles.

These findings would need to be corroborated in larger datasets, but invite caution in the interpretation of data, including data for dubbing perhaps, despite the differences with subtitling. With little or no reduction in dubbing, conversational 
routines and greetings terms can be expected to be more frequent, as these data and the data discussed in Bonsignori, Bruti et al. (2011) suggest. Frequency is still likely to be relative by comparison with naturally occurring speech. And both source and dubbed dialogues are equally likely to be representations harnessed to narrative requirements, with evidence of pragmatic indexing. This is documented by Pavesi for other features like pronouns (2009b) and demonstratives (2014), which are shown in her dubbing data to convey pragmatic meaning and sociolinguistic variation symbolically. There may be thus so as not to interpret these features at their face value in dubbing either, and to be mindful of possible internal pragmatic settings.

\subsection{Stylization, Representation and Sensitization to Otherness}

Representation of communicative practices in film subtitles cannot be literal and is not. Film subtitles in this sense call for an inescapable suspension of linguistic disbelief on the part of audiences, as Romero Fresco also notes for dubbing (2009), for going along with the linguistic make-belief set up in the service of narrative. This raises another inevitable question: to what extent do linguistic adaptations and the suspension of disbelief associated with them relate to, and can be a tool for, linguistic representation. The impact of the pragmatic mismatch noted earlier, between the source language conversational practices portrayed in foreign films and the pragmatic expectations that the target language of the subtitles may activate for them is an important consideration: misguided expectations could arguably have the effect of promoting or reinforcing linguistic typecasting, particularly if primed by stereotypical perceptions of the source language (e.g. French people as rude).

The argument pursued here is that subtitles have scope to alert audiences to differences in conversational practices and verbal negotiation and their otherness, in spite of, or even thanks to, their inescapable stylization. The case is made this time with examples from Volver (Almodóvar 2006).

Example (9), a market stall exchange from Volver (Almodóvar 2006) is an echo for Spanish of previous examples for French. It involves the stall holder (SH) and Raimunda (R) (main female character in the film). There is no please or thank you in the English subtitles, in a buying/selling exchange in which these features of politeness might be expected. However, as in earlier examples for French, pragmatic internal settings and triggers can be argued to cue that politeness conventions set up internally are adhered to. The stall seller Sure at the close of the exchange in subtitle [3] signals a positive orientation and confirms retrospectively that no violation of politeness conventions appears to have occurred. It was used in this way in an earlier scene, in which it was set up to fulfil this function after an overt accepted apology.

The exchange depicted in the subtitles may fall short of expectations from the perspective of English and English native speakers, as out of line with communicative preferences in this kind of exchange. Because the characters on screen de facto validate the exchange as pragmatically appropriate, it is enough to suggest, on the other hand, that politeness for this kind of encounter may be constructed differently in Spanish, i.e. with fewer overt markers like please and thank you. This is indeed what studies in pragmatics do suggest (De Pablos-Ortega 2010). 
(9) [Subtitles] [30.09]

$1 \mathrm{SH}$

$\mathrm{R} \quad$ - Give me another two kilos.

$2 \mathrm{R}-$ How much are the potatoes? $\mathrm{SH} \quad-1.60$ for four kilos

$3 \mathrm{R} \quad-$ Give me eight kilos.

$\rightarrow \quad \mathrm{SH}$ - Sure.
[SD]

dos kilos/

me pone dos kilos más/

muybien/

¿a cómo tiene las patatas?/

las patatas/las tenemos/cuatro kilos/

uno con sesenta/

me pones ocho kilos/

muybien/

(Volver, Almodóvar 2006)

This kind of feature may not seem much to go by in the way of representation, but could be sufficient at least to foil unhelpful stereotyping and alert viewers to pragmatic otherness. They are not isolated occurrences in any case. There are also other more overtly represented types of patterns, for example for leave taking in Volver (Almodóvar 2006). Leave taking sequences in the film are speech events where key details for taking the narrative forward are introduced. There is a number of them in the film, all with the same macro-structure reminiscent of the Béal/Traverso framework for front door rituals. As shown in the two examples displayed side by side in Table 2 they share several marked features:

- the actual leave taking is always announced - e.g. We are leaving now. [1] in the first exchange [3.14] [1], We have to leave [1] in the second exchange [10.40];

- it is only taking place sometime after it is first mooted, sometimes long after, with small (or not so small) talk in between (after 8 and 20 subtitle lines in the first and second respectively);

- it involves hugs and/or kisses depending on the degree of exchange partners' familiarity;

- it closes with a good wishes adjacency pair which finally heralds actual departure (Mind how you go!/We'll do that. I love you lots [7] in the first exchange [7], Safe journey/[no second pair part] [16] in the second exchange (2).

Leave taking is portrayed as a long-drawn out affair, in contrast to what may be called for in other languages, cultures and contexts. Its representations thus have the potential to point to the kinds of difference in conversational styles and underlying cultural values that Béal and Traverso draw to attention for front door rituals in French and Australian English.

These features would need to be compared across languages, and are a function of source dialogues and what is seen on screen rather than features of subtitles specifically. They nonetheless have a degree of specificity resonant of the stylized conventions discussed earlier and manifest in the repetition of similar phrases (we're leaving/ we have to leave), for example, that cue the recurrence of patterns in exchanges and activate receptive sensitivity. 


\section{TABLE 2}

Leave-taking patterns in Volver (Almodóvar 2006)

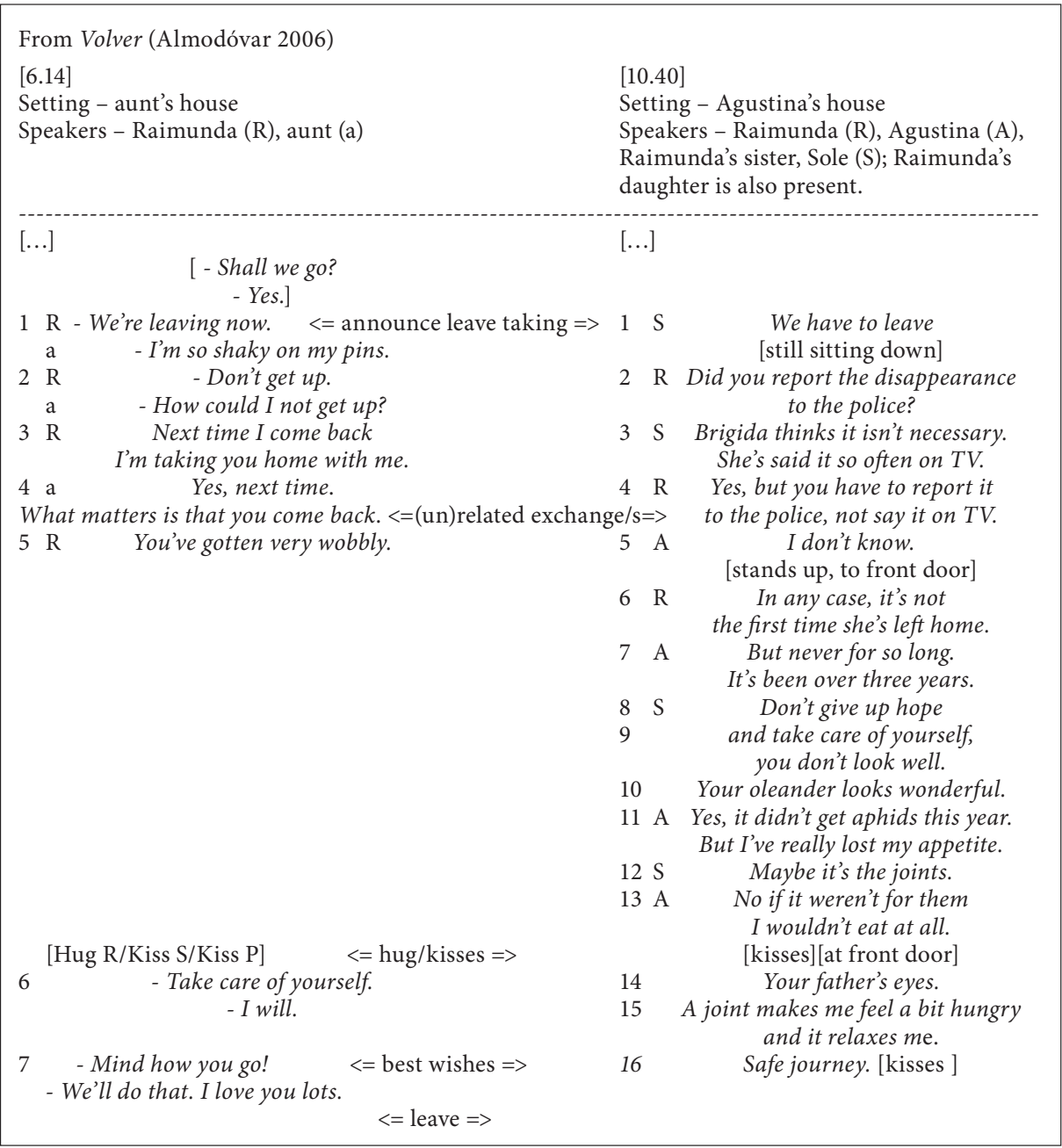

\section{Linguistic and Pragmatic Adaptation - A Tool for Linguistic and Cultural Representation?}

With this qualitative case study of a small dataset of films subtitled into English from French and Spanish, further evidence has been uncovered of the potential of subtitles to generate their own sets of pragmatic conventions and settings, at the micro and macro levels - linguistic design of speech events and structural patterning of conversational routines. As noted in the earlier studies expanded on here, the features documented could seem relatively insignificant on their own. They may cumulatively have the capacity to inflect audiences' responses to otherness to a greater extent than we may yet be in a position to assess. From the cross-cultural pragmatics perspective of this case study, conclusions and implications are thus threefold: 
- the linguistic and pragmatic adaptive practices in evidence in the text of subtitles appear to be more effective tools for linguistic and cultural representation than has hitherto been recognized;

- the extent of these representations, and their nature in relation to both their fictional representation in source dialogues and naturally occurring speech, is not yet sufficiently documented, and would/will require (more) systematic mapping out;

- we do not know either what impact these stylized linguistic and cultural representations may have on audiences, including in their interplay with films' other semiotic resources, and that, too, would need to be assessed (do they reinforce or combat stereotypes, for example?). Reception studies have focused on various phenomena (e.g. cognitive processing in Bairstow 2011, reception strategies in Tuominen 2011). None has yet focused on subtitles from a cross-cultural pragmatics and representational perspective. Evaluating audiences' perceptions of, and responses to, linguistic and cultural otherness is methodologically complex given the range of factors involved and the sociocultural heterogeneity of viewing publics (Guillot 2012b). What is at stake in view of the global circulation of foreign films and cultural products makes it worth undertaking.

These activities entail access to more data than are currently available, however: full sets of subtitles across different languages, input from pragmatics and crosscultural pragmatics, also still limited to most common languages and a limited range of speech events, and/or authentic speech data as a baseline. The size and complexity of what is involved in this kind of research may well explain why it has been limited so far. Corpus-based work has been gaining ground in audiovisual translation research and will provide greater opportunities to achieve greater consistency in approaches and to pool findings in a coordinated way.

There is a strong echo in some practical guides to subtitling of phenomena and features highlighted in the foregoing analyses. Bannon's (2013) comments about some of his own practices as a film subtitler, for example, provide clear evidence of internal pragmatic indexing and setting up of conventions, that can become simple reminding hints as viewers become used to them ${ }^{6}$. There is also mounting evidence in AVT studies and publications of the last three or four years of the distinctive creative potential of subtitles, and of the public's appetite for more culturally and linguistically other-evocative interlingual accounts of source dialogues (Casarini 2012; Franzelli 2011; De Meo 2012; Longo 2009; Tortoriello 2012). The capacity of subtitles to respond to these aspirations has been accommodated more literally and liberally in amateur subtitling practices, where they have been a catalyst in promoting changes of perspective, in practices and in research approaches (Díaz Cintas and Remael 2007; PérezGonzàlez 2014). Its potential in mainstream subtitling warrants more systematic investigation.

\section{NOTES}

1. Audiard, Jacques (2001): Sur mes lèvres / Read My Lips, DVD version @ 2001 . Sedif-Cine B-Pathe Image Production - France 2 Cinema.

2. Klapish, Cédric (2008): Paris. DVD version 2006 @ Ce Qui Me Meut - StudioCanal - StudioCanal Image - France 2 Cinéma.

3. Haneke, Michael (2005): Caché / Hidden, DVD version (c) 2005 Artificial Eye.

4. Almodóvar, Pedro (2006): Volver. DVD 2006 @ El Deseo. D.A. S.L.U.

5. Remarkably, these two scenes are each the first in a set built on, and developed entirely around, greeting interactions in the same contexts (5 in each case), in stand-alone narrative strands. The 
bakery narrative depicts an archetypal shopkeeper - small-minded, exploitative of her staff, racially prejudiced and self-righteous, whose jolly greeting demeanour with her customers is set throughout against her abusive verbal behaviour and attitude to her trainee shop assistants. The market stall narrative is used as the backdrop for the development of the romantic relationship referred to in the article text and is likewise driven forward exclusively through greeting scenes, that are increasingly stylized.

6. Having ascertained that "fictional worlds have rules of their own" (2013: 5), Bannon thus notes about the repetition of yeah? at the end of a line that it matches a particular character's accent in the opening scene of the film discussed. He goes on to add that "later the accent is toned down but crops up occasionally as a reminder of the young man's background" and that "similarly, in the subtitles, yeah is used in moderation for the same purpose" (Bannon 2013: 39). He recommends using dialects sparingly, establishing the rules on usage early and sticking to them, noting that "Viewers will soon adapt to variations in spelling and infer that the character's dialogue has a unique sound that is replicated in the subtitles" (Bannon 2013: 46). He observes that it would be pointless repeatedly to subtitle a greeting he is discussing - Guten Abend [Good evening] since the audience has heard and read the translation when it was first spoken (Bannon 2013: 133), etc.

\section{REFERENCES}

Bannon, David (2009/2013): The Elements of Subtitles: A Practical Guide to the Art of Dialogue, Character, Context, Tone and Style in film and televisionsubtitling. $3^{\text {rd }}$ edition. Blackstock: Translation Studies Press.

BÉAL, Christine and Traverso, Véronique (2010): "Hello, we're outrageously punctual": front door rituals between friends in Australia and France. Journal of French Language Studies. 20(1):17-29.

BÉAL, Christine (1992): Did you have a good weekend: or why there is no such thing as a simple question in cross-cultural encounters. Australian Review of Applied Linguistics. 15(1):23-52.

BÉAL, Christine (2010): Les interactions quotidiennes en français et en anglais: De l'approche comparative à l'analyse des situations interculturelles. Bern: Peter Lang.

BAIrstow, Dominique (2011): Audiovisual processing while watching subtitled films: a cognitive approach. In: Adriana Şerban, Anna Matamala and Jean-Marc Lavaur, eds. Audiovisual Translation in Close-up: Practical and Theoretical Approaches. Bern: Peter Lang, 205-217.

Bonsignori, Veronica, Bruti, Silvia and MAsi, Silvia (2011): Formulae across languages: English greetings, leave-takings and good wishes in dubbed Italian. In: Adriana ŞERBAN, Anna Matamala and Jean-Marc Lavaur, eds. Audiovisual Translation in Close-up: Practical and Theoretical Approaches, Bern: Peter Lang, 23-44.

Brown, Penelope, Levinson, Stephen (1987): Politeness: Some Universals in Language Use. Cambridge: Cambridge University Press.

Bruti, Silvia (2006): Cross-cultural pragmatics: the translation of implicit compliments in subtitles. The Journal of Specialized Translation 6. http://www.jostrans.org/issue06/art_ bruti.pdf

Bruti, Silvia (2009a): The translation of compliments in subtitles. In: Jorge Díaz Cintas, ed. New Trends in Audiovisual Translation. Clevedon: Multilingual Matters, 226-238.

Bruti, Silvia (2009b): Translating compliments and insults in the Pavia corpus of film dialogues: two sides of the same coin? In: Maria Freddi and Maria PAvesi, eds. Analysing Audiovisual Dialogue: Linguistic and Translational insights. Bologna: CLUEB, 143-163.

CASARInI, Alice (2012): XOXO: gossip girl and dubbing in the age of 'net lingo.' In: Silvia Bruti and Elena Di Giovanni, eds. Audiovisual Translation across Europe: An Ever-changing Landscape, New trends in translation studies. Vol. 7. Bern: Peter Lang, 59-78.

De Meo, Maria Grazia (2012): Subtitling dialects: strategies of socio-cultural transfer from Italian into English.. In: Silvia Bruti and Elena Di Giovanni, eds. Audiovisual Translation across Europe: An Ever-changing Landscape, New trends in translation studies. Vol. 7. Bern: Peter Lang, 79-96. 
De Pablos-Ortega, Carlos (2010): Attitudes of English speakers towards thanking in Spanish. Pragmatics. 20(2):201-222.

Desilla, Louisa (2009): Towards a Methodology for the Study of Implicatures in Subtitled Films: Multimodal Construal and Reception of Pragmatic Meaning across Cultures, Unpublished $\mathrm{PhD}$ Thesis, University of Manchester.

Díaz Cintas, Jorge and Remael, Aline (2007): Audiovisual Translation: Subtitling. Manchester: St Jerome Publishing.

Fowler, Roger (1991): Language in the News: Discourse and Ideology in the Press. London: Routledge.

Fowler, Roger (2000): Orality and the theory of mode in advertisements. In: Marie-Noëlle Guillot and Marie-Madeleine Kenning, eds. Changing Landscapes in Language and Language Pedagogy. London: AFLS/CiLT, 26-39.

Franzelli, Valeria (2011): Fortes émotions: décrire et sous-titrer des séquences de colère, unités de sens filmique. In: Adriana ŞERban and Jean-Marc Lavaur, eds. Traduction et médias audiovisuels. Villeneuve d'Ascq: Presses Universitaires du Septentrion, 123-137.

Guillot, Marie-Noëlle (2007): Oral et illusion d'oral: indices d'oralité dans les sous-titres de dialogues de film. META. 52(2):239-259.

Guillot, Marie-Noëlle (2008): Orality and film subtitling: the riches of punctuation. The Sign Language Translator and Interpreter. 2(2):127-147.

Guillot, Marie-Noëlle (2010): Film subtitles from a cross-cultural pragmatics perspective: issues of linguistic and cultural representation. The Translator. 16(1):67-92.

Guillot, Marie-Noëlle (2012a): Stylization and representation in subtitles: can less be more? Perspectives: Studies in Translatology. 20(4):479-494.

Guillot, Marie-Noëlle (2012b): Film subtitles and the conundrum of linguistic and cultural representation: a methodological blind spot. In: Martin LuginbüHL and Stefan Hauser, eds. Contrastive Media Analysis. Amsterdam: John Benjamins, 101-122.

Hatim, Basil, Mason, Ian (1997): The Translator as Communicator. London: Routledge.

House, Juliane (2005): Politeness in Germany: politeness in Germany? In: Leo Hickey and Miranda Stewart, eds. Politeness in Europe. Clevedon: Multilingual Matters, 13-28.

Kerbrat-Orecchioni, Catherine (2005): Politeness in France: how to buy bread politely. In: Leo Hickey and Miranda Stewart, eds. Politeness in Europe. Clevedon: Multilingual Matters, 29-44.

Longo, Abele (2009): Subtitling the Italian South. In: Jorge Díaz Cintas, ed. New trends in audiovisual translation. Clevedon: Multilingual Matters, 99-108.

Pavesi, Maria (2009a): Dubbing English into Italian: a closer look at the translation of the spoken language. In: Jorge DíAz Cintas, ed. New trends in audiovisual translation. Clevedon: Multilingual Matter, 197-209.

Pavesi, Maria (2009b): Pronouns in film dubbing and the dynamics of audiovisual communication. VIAL - Vigo International Journal of Applied Linguistics. 6:89-107.

Pavesi, Maria (2014): This and that in the language of film dubbing: a corpus-based analysis. Meta. 58(1):107-137.

Pérez-GonzÀlez, Luis (2014): Audiovisual Translation: Theories, Methods and Issues. Oxon: Routledge.

Pinto, Derrin (2010): Lost in subtitle translations: the case of advice in the English subtitles of Spanish films. Intercultural Pragmatics. 7(2):257-277.

Ranzato, Irene (2010): Localising Cockney: translating dialect into Italian. In: Jorge Díaz Cintas, Anna Matamala and Josélia Neves, eds. New Insights into Audiovisual Translation and Media Accessibility: Media for All 2. Amsterdam: Rodopi, 109-122.

Romero Fresco, Pablo (2006): The Spanish dubbese: a case of (un)idiomatic Friends. Journal of specialised translation 6. <http://www.jostrans.org/issue06/art_romero_fresco.pdf >.

Romero Fresco, Pablo (2009): Naturalness in the Spanish dubbing language: a case of not-soclose Friends. Meta. 54(1):49-72.

SEnft, Gunther (2014): Understanding Pragmatics. Oxon: Routledge. 
Tortoriello, Adriana (2012): Lost in subtitling? The case of geographically connotated language. In Silvia Bruti and Elena Di Giovanni, eds. Audiovisual Translation across Europe: An Ever-changing Landscape. New trends in translation studies Vol. 7. Bern: Peter Lang, 97-112.

Tuominen, Tina (2011): Accidental reading? Some observations on the reception of subtitled films. In: Adriana Şerban, Anna Matamala and Jean-Marc Lavaur, eds. Audiovisual Translation in Close-up: Practical and Theoretical Approaches. Bern: Peter Lang, 189-204. Yule, George (1996): Pragmatics. Oxford: Oxford University Press. 